\title{
Annelerin okuma yazmaya hazırlık sürecine ilişkin görüşleri
}

\section{Views of mothers regarding early literacy process}

\begin{abstract}
Şenay Özen Altınkaynak ${ }^{1}$
Makale Geçmişi

Geliş : : 11 Şubat 2019

Düzeltme : 15 Mart 2019

Kabul : 19 Mart 2019

Çevrimiçi : 20 Mart 2019

\section{Makale Türü}

Arastrma Makalesi

\section{Article History}

Received : 11 February 2019

Revised : 15 March 2019

Accepted : 19 March 2019

Online : 20 March 2019

\section{Article Type}

Research Article

Öz: $\mathrm{Bu}$ araştırmanın amacı, annelerin okuma yazmaya hazırlık sürecine ilişkin görüşlerinin belirlenmesidir. Nitel desende yürütülen araştırma sürecinde uygulanan Aile Temelli Okuma Yazmaya Hazırlık Programının öncesinde ve sonrasında aileler ile yarı yapılandırılmış görüşmeler yapılmıştır. Araştırmanın çalışma grubu, Kars ilinde Milli Eğitim Bakanlığı'na bağlı bir ilkokulun anasınıfında eğitimin gören 25 anne oluşturmaktadır. Araştırmanın verilerini elde etmek için yarı yapılandırılmış görüşme formu kullanılmıştır. Araştırmada ailelerin okuma yazmaya hazırlık sürecine ilişkin görüşlerini ve uygulamalarını belirlemek için içerik analizi yapılmıştır. Elde edilen bulgular, uygulanan programının öncesinde ve sonrasında ailelerle yapılan görüşmelerin farklılaştığını, ikinci görüşmelerde ailelerin okuma yazmaya hazırlık sürecine ilişkin görüşlerinin ve uygulamalarının olumlu yönde değiştiğini göstermiştir.

Anahtar Kelimeler: Aile Temelli Okuma Yazmaya Hazırlık Programı, Okuma yazmaya hazırlık, Okul öncesi eğitim

Abstract: The purpose of the current study is to determine the opinions of mothers about the literacy preparation process. Semi-structured interviews were conducted with families before and after the Family Literacy Program within the context of the current research conducted according to the qualitative research design. The study group of the current research is comprised of 25 mothers and their children attending a nursery class of a state elementary school located in the city of Kars. The data of the study were collected by using a semi-structured interview form developed by the researcher. Content analysis was run on the collected data to determine the families' opinions and practices in relation to the literacy preparation process. The findings obtained have revealed that the Family-Based Literacy Preparation Program had positive effects on the opinions and practices of families regarding the literacy preparation process.
\end{abstract}

Keywords: Family Based Reading and Writing Preparation Program, Early literacy, Preschool education

${ }^{1}$ Kafkas Üniversitesi, Eğitim Fakültesi, Okul Öncesi Eğitimi Ana Bilim Dalı, ozensenay@gmail.com, ORCID: https://orcid.org/0000-0002-6614$\underline{4168}$ 


\section{SUMMARY}

\section{Introduction}

It is important to monitor the effects of correct and effective literacy preparation programs directed to families on both families and children in the short and long term. The purpose of the current study is to determine the opinions of mothers about the literacy preparation process. The findings obtained have revealed that the Family Literacy Program had positive effects on the opinions and practices of families regarding the literacy preparation process.

\section{Method}

Semi-structured interviews were conducted with families before and after the implementation of the FamilyBased Literacy Preparation Program within the context of the current research conducted according to the qualitative research design. The study group of the current research is comprised of 25 mothers and their children attending a nursery class of a state elementary school located in the city of Kars. The data of the study were collected by using a semi-structured interview form developed by the researcher. Content analysis was run on the collected data to determine the families' opinions and practices in relation to the literacy preparation process.

\section{Results}

As a result of the study, differences and variety were observed in the descriptions and explanations of the mothers made during the second interviews. While the mothers were explaining the literacy preparation skills, they mostly focused on preparation for writing and alphabet knowledge during the first interviews; yet, they overlooked other skills to a great extent. However, after the implementation of the program, the mothers made explanations putting emphasis on all the literacy preparation skills. This finding indicated that the implemented program had positive effects on the families' opinions about the literacy preparation skills. Moreover, during the second interviews, majority of the families expressed positive opinions about the role of families in the literacy preparation process. During the interviews conducted after the completion of the program, the mothers emphasized that families should take responsibility for the planning and implementation of literacy preparation activities and for raising the awareness of literacy and developing positive attitudes towards it and stated that they should avoid practices not conducive to the development of literacy.

When the explanations made during the second interviews by the participating mothers were examined, it was seen that the opportunities they provided for their children at home increased. This is believed to be because of the training program they participated in. In the Family-Based Literacy Preparation Program, families can gain a lot of information and skills in relation to the content and implementation of a literacy preparation process. The families are thought to be using what they have learned during the program at home. All these findings show that the Family Literacy Program had effects on the practices done by the families in relation to literacy preparation at home. 
Majority of the mothers participating in the current study stated that after they had participated in the program, they observed positive responses of their children to literacy preparation activities. Only 5 mothers emphasized the psycho-motor deficiencies such as not being able to hold the pencil and experiencing difficulties in drawing activities.

\section{Conclusion and Discussion}

As a result of the current study exploring the mothers' opinions and practices in relation to early literacy, it was found that after the implementation of the Family-Based Literacy Preparation Program, the families' opinions about the literacy preparation process had changed and this process led to creating more literacy opportunities at home, planning and implementation of literacy activities at home and reduction of activities not conducive to literacy development. In light of the findings of the current study, the following suggestions can be made: family literacy programs with varying intensities and different dimensions should be developed as in other countries and research on the effects of such programs can be conducted. As there is limited research on family literacy programs in our country, meta-analysis studies can be conducted so that comparisons can be made between the family literacy programs addressed in the international literature. 


\section{GİRIş}

Dünyada okul öncesi yılların önemi ve çocukların gelişimindeki rolü konusunda yükselen bilinç düzeyi, erken yıllardaki eğitimin yaygınlaşmasını sağlamakla birlikte niteliğin dikkate alınmasına da dikkat çekmiştir. Bu bağlamda, okul öncesi eğitimin yaygınlaştırılması ve eğitimin niteliğinin arttırılması önemlidir. Bu durum anne ve babalarla yapılan işbirliği ile onların eğitimine katkı sağlamayı, eğitim sürecine katmayı gerektirir. Günümüzde eğitimciler çocukların gelişimlerini ve eğitimlerini desteklemek için etkin aile katılımının gerekliliğini savunmaktadır. (Erkan, 2013; Kalkan, 2010). Evde çocuklar için hazırlanan öğrenme firsatlarının çocuklarda okula hazır olma sürecini etkilediğini ortaya koyan araştırmalar ev öğrenme ortamlarının iyileştirilmesi gerektiğini belirtirler. Unutkan (2007) 5-6 yaşındaki çocukların yaşadıkları evin, çocukların ilkokula hazır bulunuşluk becerilerine etkisini incelemiş, çocukların yaşadıkları evin özelliklerine göre çocukların okula hazır olma düzeylerinin, matematik, bilişsel-dil gelişimi ile öz bakım becerileri açısından farklılık olduğu, fiziksel gelişim açısından ise herhangi bir farklılık olmadığı belirlenmiştir. Polat (2011) tarafından evde bulunan teknolojik araçların çocukların okula hazırlık becerilerine etkisinin incelendiği araştırmada, teknoloji yönünden ev ortamlarının iyileştirilmesinin ve ilkokula hazır bulunuşluk açısından böyle ortamlar oluşturulmasının önemli olduğunu vurgulamıştır.

Çocukların okuryazarlık becerilerinin gelişiminde erken yılların önemi dikkate alındığında, okul öncesi dönemde yetişkinlerin çocuklara sağladıkları firsatlar önem kazanmaktadır. Eğitim kurumları çocuklar için bu amaçları gerçekleştirmeye yönelik eşsiz firsatlar sunarlar. Bu süreçte öğretmenlerin etkili bir rehber, okul öncesi eğitim programının da iyi bir yönlendirici olması beklenir. Bu dinamik programlarla sağlanabilir (Güleç, 2008). Türkiye'de okul öncesi eğitime yönelik kurumlarda erken okuryazarlık becerilerini destekleyecek programlar mevcuttur ancak yapılan araştırmalar sonucunda aileler için hazırlanan bir tane okuma yazmaya hazırlık programına rastlanmıştır. Büyüktaşkapu (2012) tarafından geliştirilen Aile Destekli Okumaya Hazırlık Eğitim Programı, 13 hafta süren, çocukların ilköğretim dönemindeki okuma yazma eğitimlerinde ihtiyaç duyacakları konularda ailelere eğitimler veren bir programdır. Eğitim programı 20 sayfalık 13 çalışma kitapçığı ile yürütülmektedir. Çalışma kitaplarında ailelerin çocuklarıyla birlikte yapacakları alıştırmalar bulunmaktadır. Bu programın daha çok okuma yazma etkinliklerine dayalı olduğu görülmektedir. Ailelere yönelik programların geliştirilerek uygulanması ilgili alandaki eksikliklerin giderilmesi ve diğer çalışmalara fikir vermesi nedeniyle önemlidir (Özen Altınkaynak, 2014).

Nitelikli bir okul öncesi eğitimin en önemli bileşenlerinden biri ailelerin eğitim sürecine etkin katılımının sağlanmasıdır. Okul öncesine hizmet eden kurumlarda uygulanan "aile eğitimi ve aile katılım çalışmaları” göz önüne alındığında; çocukların gelişimleri ile ilgili aileleri bilgilendirme, 
ekonomik destek talep etme konularında sınırlı katılım çalışmaları ile iletissim, duygusal ve sosyal gelişim, çocuk yetiştirme tutumları ile sınırlı aile eğitim çalışmalarının olduğu görülmektedir. Okul öncesi eğitim kurumlarında aile eğitimi ve katılımına ilişkin amaca hizmet eden planlamalar yapılmaması, katılım çalışmalarının az sayıda ve zayıf içerikte olması bu tür programlara duyulan ihtiyac1 göstermektedir. Çocuklara ve ailelerine önemli katkıları olan "aile eğitimi ve katılımı çalışmalarını" rastgele yapmak yerine, ihtiyaçları karşılamaya yönelik, sistemli ve nitelikli programlarla yürütmek bu sürecin verimini arttıracaktır (Özen Altınkaynak, 2014).

Ailelerin çocuk gelişiminde ve eğitiminde üstlendiği rol, eğitim sürecine etkin katılımları ile çocukların akademik başarısı arasındaki ilişkiyi göz önüne alma son yıllarda alan yazında daha çok önem kazanmıştır (Carson, 2009). Bu anlayış, öğretmen yetiştirmeye yönelik uluslararası programların ailelerle çalışmaya yönelik standartlarını oluşturmasına yol açmıştır. Amerika Birleşik Devletleri'nde, öğretmen yetiştiren programların aileleri destekleyecek ve güçlendirecek saygılı ve karşıllklı ilişkileri oluşturabilecek öğretmenler yetiştirmesi ve çocukların gelişimi ile eğitiminde ailelerin etkin katılım göstermesi bu standartların gereğidir (NAEYC, 2011). Yeni Zelanda'da ise öğretmenlerin aileler, bakıcılar ve topluluklar ile etkin şekilde çalışacak bilgi dağarcı̆̆ına ve eğilimine sahip olması gerekli standartlardandır (Mahmood, 2013). İngiltere'de "Nitelikli Öğretmen Statüsüne Yönelik Profesyonel Standartları” ile öğretmenlerin, ailelerin ve bakıcıların etkisini göz önünde bulundurmaları ve buna sayg1 duymaları şart koşulur. Avustralya, öğretmenlerden profesyonel anlamda aile, bakıcı ve toplum ile iç içe olmalarını bekler. (Training and Development Agencyfor Schools, 2008).

Türkiye'deki programlar incelendiğinde, çocukların erken okuryazarlık becerilerini desteklemeye yönelik aileler için hazırlanmış programlar bulunmamaktadır. Ülkemizde okuma yazmaya hazırlık konusuna ilişkin planlı ve uzun vadeli programlar bulunmamaktadır ancak "573 sayılı Kanun Hükmünde Kararname”ye dayanarak 2000 yılında yürürlüğe konulan ve 31.05 .2006 tarihinde değişikliklerle yürürlüğe konulan “Özel Eğitim Hizmetleri Yönetmeliği”nde, özel gereksinimi olan kişilerin eğitiminde aile katılımının gerekliliği yeniden vurgulanmıştır (akt. Gül, 2007). 2006 yılında Aile ve Sosyal Araştırmalar Genel Müdürlüğü ve TÜBİTAK işbirliğinde gerçekleştirilen ve kamu kurum/kuruluşları, üniversiteler, sivil toplum kuruluşları temsilcilerinin katıldığı "Ulusal Aile ve Sosyal Araştırmalar Kamu Araştırma Raporu”nda, toplumsal hayata aktif katılımı amaçlayan "Aile Okuryazarllğı” projesinden bahsedilmiştir. Fakat planlanan bu proje aile eğitimi ve bireysel gelişim gibi toplumsal ve kişisel gelişime yönelik konularla sınırlandırılmıştır (Ulusal Aile ve Sosyal Araştırmalar Kamu Araştırma Programı, 2006). Ülkemizde ailelere yönelik kapsamlı okuma yazmaya hazırlık programları olmamasına rağmen, okuma yazmaya hazırlık sürecindeki rollerini 
vurgulayan, eğitim, gelir ve sosyoekonomik düzeyleri ile çocuklara sağladıkları okuma-yazma fırsatları arasındaki ilişkiyi ortaya koyan araştırmalar mevcuttur (Altıparmak, 2010; Baydar, Kuntay, Gökşen, Yağmurlu ve Cemalc1lar, 2010; Gülec, Genc ve Şahan, 2014; Özbek Ayaz, 2015).

Hannon ve Weinberger'e (2003) göre, aile okuryazarlığ1 kavramı ilk olarak Amerika Birleşik Devletleri'nde ortaya çıkmıştır. Bu ifadeyi ilk defa Taylor kullanmıştır. Denny Taylor'un, 1983 yılında yayınladığı kitabı ile aile okuryaz̧arlğ̆ terimi popüler hale gelmiştir. O yıllarda Amerika Birleşik Devletlerinde, finans desteği sağlanan ve aktif olan 500'den fazla aile okuryazarlık programının olduğu belirtilmiştir (Harper, Platt, Pelletier, 2011).

Aile okuryazarlığı, okuma yazma inançlarının, uygulamalarının ve okuma yazmanın kuşaktan kuşağa aktarılmasıdır (Wasik and Herrmann, 2004). Ailelere yönelik okuma yazma çalışmaları, ev ortamında okuma yazma öğretimi konusunda iki önemli konuya dikkat çekmiştir: (1) ailedeki bireyler okuma yazmayı öğrenme, geliştirme ve kullanma konusunda çocuklarını teşvik edici okuryazarlık bilgisine sahip olmalıdır. (2) Çocuklar kitaplara erişebilmeli ve çocukların okuma yazma gelişimleri üzerinde olumlu bir etki bırakmalıdır (Saracho, 2000).

Aile okuryazarlık programları çocuklara, yetişkinlere, ailelere, okullara ve topluma pek çok fayda sağlar. Bu programlar, ailelere okuryazarlık konusunda öğrendiklerini uygulayabilme firsatı sunarken aile-çocuk etkileşimlerini geliştirecekleri fırsatlar verir. Programlara katılan ailelerin çocuklarıyla etkileşimleri artar, etkinliklerinde kullanabilecekleri stratejiler (sesli kitap okuma, hikâyedekileri canlandırabilme, çeşitli türlerde kitaplar okuma, resim, karakter ve konuları tartışma gibi) edinebileceklerdir. Ailelerin çocuk eğitimine verdikleri önem, olumlu okuma alısskanlıkları, çocuklarının gelişimi hakkındaki bilgileri, özgüvenleri, eğitime katılım oranları, çocukları için okuma yazma ortamı oluşturma becerilerine ilişkin farkındalık düzeyleri artar. Yapılan araştırmalar, bu programlardan yararlanan ailelerin çocuklarına sıkça kitap okuduklarını, kütüphanede daha çok zaman geçirdiklerini ve sınıftaki etkinliklere katılım konusunda daha istekli davrandıklarını ortaya koymuştur (Saracho, 2007; Rasinski ve Stevenson, 2005; Swain, Brooks ve Bosley, 2014). Bu bağlamda, okuma yazmaya hazırllğga ilişkin ailelerin sahip oldukları bilgiler, tutum ve davranışlarını şekillendirdiği gibi çocukların okuryazarlığa karşı ilgilerini, tutum ve becerilerini de etkiler. Ancak ailelerin okuma yazmaya hazırlık becerilerine yönelik yanlış ya da eksik bilgileri ve olumsuz tutumları önemli bir eksikliktir. Ailelerin okuma yazmaya hazırlık sürecine ilişkin görüşleri, bu konuda çocukların gelişimine uygun olmayan yanlış tutum ve davranışların belirlenmesi, bu konuda müdahale programlarının gerekliliğine dikkat çekilmesi açısından önemlidir (Özen Altınkaynak, 
2014). Bu bağlamda çalışmanın amacı, ailelerin okuma yazmaya hazırlık konusundaki görüşlerinin ve uygulamalarının belirlenmesidir.

\section{YÖNTEM}

Ailelerin erken okuryazarlık konusundaki görüş ve uygulamalarının incelendiği bu araştırma nitel araştırma modeli ile yürütülmüştür. Nitel araştırma modeli ile yürütülen bu araştırmada ayrıntılı şekilde verilerin elde edilmesi, katılımcıların bireysel algıları, deneyimleri ve bakış açılarının doğrudan belirlenmesi ve mevcut durumlarının anlaşılması amaçlanmıştır (Büyüköztürk, Kılıç Çakmak, Akgün, Karadeniz ve Demirel, 2014).

\section{Çalışma Grubu}

Araştırmanın çalışma grubunu, çocukları Kars ilinde Milli Eğitim Bakanlığı'na bağlı bir ilkokulun anasınıfında eğitim göre 25 anne oluşturmaktadır. Çalışmaya başlamadan önce il Milli Eğitim Müdürlüğünden bilgi alınarak sosyoekonomik düzeyi çeşitlilik gösteren bir ilkokul belirlenmiştir. $\mathrm{Bu}$ ilkokulda alt, orta ve üst sosyoekonomik düzeyine sahip aileler olması nedeniyle araştırmaya dahil edilmiştir. İlkokuldaki 3 anasınıfina çocukları devam eden aileler ile toplantı yapılmıştır. Toplantıda araştırmanın içeriğinden bahsedilmiş, gönüllülük formu dağıtılmıştır. Gönüllü katılımın en fazla olduğu sınıf araştırmanın çalışma grubu olarak belirlenmiştir. Annelerin 2'si ilkokul, 5’i ortaokul, 8'i lise, 7'si üniversite, 3'ü ise lisansüstü eğitim mezunudur. Annelerin yaş aralı̆̆1 22 ile 42 arasında değişmektedir. Annelerin 4’ü bir çocuk, 12'si iki çocuk, 6’s1 3 çocuk ve 3’ü dört ve üzeri sayıda çocuk sahibidir. Araştırmaya katılan annelerin 13’ü herhangi bir işte çalışırken 12'si çalışmadığını belirtmiştir.

\section{Veri Toplama Araçları}

Araştırmanın verileri araştırmacı tarafından geliştirilen yar yapılandırlmış görüsme formu ile toplanmıştır. Bu amaçla araştırmacı tarafından ilgili alan yazın incelenerek hazırlanan ve dört ilgili alan uzmanının (üç okul öncesi eğitimi, bir ölçme ve değerlendirme uzmanı) görüşüne başvurularak son şekli verilen görüşme formu iki bölümden oluşmaktadır. İlk bölümde, annelerin demografik özelliklerini belirleyen sorular bulunmaktadır. Diğer bölümde, çocuklarını okuma yazmaya hazırlama sürecinde ailelerin bilgilerini, yeterliliklerini, bu süreci olumlu ve olumsuz etkileyen tutumlarını ve rolünü belirlemeye yönelik 6 soru (Örneğin; okul öncesi dönemde okuma yazmaya hazırlık çalışmalarının gerekli olduğunu düşünüyor musunuz? Lütfen nedenleri ile belirtiniz. Çocuklarınızı okuma yazmaya hazırlamak için neler yapıyorsunuz?, Çocuklarınız okuma yazmaya hazırlama konusunda kendinizi yeterli hissediyor musunuz? gibi) yer almaktadır. Bu form ile 
ailelerin okuma yazmaya hazırlık konusundaki düşünceleri ve uygulamaları ile yeterlilik algılarının belirlenmesi amaçlanmıştır.

\section{Verilerin Toplanması ve Analizi}

Ailelerin erken okuryazarlık konusundaki görüş ve uygulamalarını belirlemek için Aile Temelli Okuma Yazmaya Hazırlık programından önce ve sonra ailelerle görüşmeler yapılmıştır. Araştırmanın verileri annelerin kendilerini rahatlıkla ifade edeceği bir ortamda ve zamanda elde edilmiştir. Katılımcılar ile birebir görüşme yapılmıştır. Nitel araştırmalarda içerik analizinde, birbirine benzeyen veriler çeşitli kodlar ve temalar altında bir araya getirilir ve okuyucunun anlayacağı bir şekilde organize edilip düzenlenerek yorumlanır (Yıldırım ve Şimşek, 2008:227). Bu bağlamda araştırmada içerik analizi yapılırken annelerin görüşlerinden hareketle belli kodlar ve temalar belirlenmiştir. Temalar, okuma yazmaya hazırlık becerilerinin tanımı/içeriği, okul öncesi dönemde okuma yazmaya hazırlık çalışmalarının gerekliliği, okuma yazmaya hazırlık sürecinde ailelerin rolü, okuma yazmaya hazırlık becerilerini desteklemek için evde yapılan çalışmalar, çocukların okuma yazmaya hazırlık çalışmalarına tepkileri, ailelerin okuma yazmaya hazırlık konusundaki yeterlik algıları şeklinde belirlenmiştir. Güvenirliği artırmak için, görüşme analizleri 2 farklı araştırmacı (okul öncesi eğitimi alan uzmanı) tarafından ayrı ayrı kodlanarak sonuçlar karşılaştırılmıştır. Katılımcıların verdikleri cevaplar "görüş birliği/ görüş ayrıllı̆̆ı" kapsamında tartışılmıştır. Güvenirlik katsayısını hesaplamak için Miles ve Hubermen (1994) tarafından önerilen formül [(Güvenirlik= Görüş birliğil/ (Görüş birliği + Görüş ayrıllı̆̆1)] kullanılmış ve araştırmanın güvenirliği \%92 olarak belirlenmiştir. Miles ve Hubermen’e göre (1994), güvenirliğin \%70’in üzerinde olması araştırmanın güvenirliğini belirtir. Bu şekilde, kodlamalar ön yargılardan ve yanlış anlamalardan uzak, ortak bir bakış açısına göre yapılmış olur. Ayrıca annelerin görüşlerinden örnekler doğrudan sunulmuştur. Program araştırmacı tarafından uygulanmıştır. Veri toplama ve analizi sürecinin ayrıntılı şekilde rapor etme, araştırmacı ve katılımcıların program süresince bir arada olmaları (uzun zaman geçirmeleri) ve katılımcılarla yüz yüze görüşmeler yaparak derinlemesine bilgiler elde etme yolu ile araştırmanın geçerliliğinin sağlanması göz önünde bulundurulmuştur. Aile Temelli Okuma Yą̧maya Hą̧ırlı Programı Yaklaşık 4 ay boyunca hafta içi üç gün yüz yüze eğitim şeklinde uygulanmıştır. Program süresince okuma yazmaya hazırlık çalışmnalarının önemi ve gerekliliğine, bu süreçte ailelerin rolüne ve çocukların okuma yazmaya hazırlık becerilerini nasıl destek olabileceklerine yönelik paylaşımlar yapılmıştır. Araştırmaya katılan ailelerin dahil oldukları Aile Temelli Okuma Yazmaya Hazırlık Programına ilişkin bilgiler şu şekilde özetlenebilir (Özen Altınkaynak, 2014): Okuma yazmaya hazırlık konusunda ailelere bilgi, beceri, tutum ve davranış kazandırmayı, hedefleyen program dört boyuttan oluşmaktadır. Birinci boyutta; ailelerin öğrenme gereksinimlerini fark etmeleri ve kişisel gelişimlerine katkı sağlamak amaçlanır. 
İkinci boyutta, okuma yazmaya hazırlık becerilerini geliştirecek ev ortamı hazırlama, aktiviteler ve materyaller geliştirme konularında ailelere destek olma hedeflenir. Programın üçüncü boyutunda ailelerin programdan edindikleri bilgi ve becerileri kullanarak çocuklarıyla nitelikli zaman geçirmeleri hedeflenir. Programın son boyutu çocukların okuma yazmaya hazırlık becerilerinin geliştirmeye yönelik etkinlikleri içermektedir. Bu etkinlikler sayesinde çocukların okula hazır bulunuşluklarının desteklenmesi planlanmaktadır. Program süresince ailelerle yüz yüze görüşmelerin yanında ev ziyaretleri ile telefon görüşmeleri yapılmıştır.

\section{BULGULAR}

Araştırmanın bu bölümünde okuma yazmaya hazırlık becerilerinin içeriği, gerekliliği, bu süreçte ailelerin rolü, evde çocuklara sağlanan firsatlar, çocukların tepkileri ve ailelerin kendilerini yeterli bulma düzeyleri konusundaki görüşlerine yer verilmiştir. Aileler ile yapılan görüşmelerden elde edilen bulgular ailelerin katıldıkları Aile Temelli Okuma Yazmaya Hazırlık Programının öncesinde ve sonrasında elde edilen bulgular olmak üzere 2 başlık altında sunulmuştur.

\section{Aile Temelli Okuma Yazmaya Hazırlık Programının Öncesinde Annelerin Okuma Yazmaya Hazırlık Konusundaki Görüşlerine İlişkin Bulgular}

Araştırma kapsamında annelere "Okuma yazmaya hazırlık becerileri denince aklınıza neler geliyor? Okuma yazmaya hazırlamak için çocuklara hangi becerileri kazandırmalıyız? soruları yöneltilmiş ve katılımcıların cevaplarına ilişkin bulgular Tablo 1'de sunulmuştur.

Tablo 1. Okuma yazmaya hazırlık becerilerinin tanımına/içeriğine ilişkin bulgular

\begin{tabular}{lc}
\hline Görüşler & $\mathrm{f}$ \\
\hline Yazma becerisini desteklemeye yönelik beceriler & 15 \\
Boyama etkinlikleri & 13 \\
Kalemi tutma & 11 \\
Alfabe bilgisine yönelik beceriler & 11 \\
Harf öğretimi & \\
Dinleme ve konuşma becerisine yönelik beceriler & 5 \\
Kitap okuma & 4 \\
Ses farkındalığ1 becerisine yönelik beceriler & \\
Aynı sesle başlayan sözcükleri bulma & \\
Sözcüklerin hangi sesle başladığını söyleme & \\
\hline
\end{tabular}

Tablo 1 incelendiğinde, anneler okuma yazmaya hazırlık becerilerini daha çok yazmaya yönelik becerilerle açıklamışlardır. Araştırmaya katılan annelerin okuma yazmaya hazırlık konusuna ilişkin sınırlı sayıda görüş bildirdikleri görülmektedir. Bu konuda 12. katılımcı görüşlerini şu şekilde ifade etmiştir.

"Boyama etkinlikleri geliyor aklıma. Bu etkinlikler sayesinde kalem tutma becerileri de gelişiyor. Hem resim yapmak çocukların hoşlarına gidiyor. Hem de düzgün kalem tutmayı zamanla öğreniyorlar” 
Katılımcılara "Okul öncesi dönemde okuma yazmaya hazırlık çalışmalarının gerekli olduğunu düşünüyor musunuz? Neden? soruları yöneltilmiş ve katılımcıların cevaplarına ilişkin bulgular Tablo 2'de sunulmuştur.

Tablo 2. Okul öncesi dönemde okuma yazmaya hazırlık çalışmalarının gerekliliğine ilişkin bulgular

\begin{tabular}{lc}
\hline Gerekliliğe İlişkin Görüşler & $\mathrm{f}$ \\
\hline Gerekli & 16 \\
Gereksiz & 7 \\
Bilmiyorum & 2 \\
\hline
\end{tabular}

Tablo 2'ye göre annelerin çoğu okul öncesi dönemde okuma yazmaya hazırlık çalışmalarının gerekli olduğunu belirtmişlerdir. Bu konuda 7. katılımcı görüşlerini şu şekilde ifade etmiştir.

"Gerekli bence. Yoksa birinci sınıfa gittiklerinde arkadaşlarından çok geri kalıyorlar. Bazı çocuklar okuma yazmaya geçerken bazıları daha harfleri yazmayı başaramıyor "

Katılımcıların okuma yazmaya hazırlık sürecinde ailelerin rolüne ilişkin görüşleri Tablo 3'de sunulmuştur.

Tablo 3. Okuma yazmaya hazırlık sürecinde ailelerin rolüne ilişkin bulgular

\begin{tabular}{lc}
\hline Görüşler & $\mathrm{f}$ \\
\hline Olumlu görüşler & 4 \\
Destek olma & 2 \\
Çocuk açısından önemini vurgulama & 10 \\
Olumsuz görüşler & 9 \\
Bilgi eksiklĭğ & 6 \\
Sorumluluğu okula ve öğretmenlere birakma & 6 \\
Yanlış beklentiler & \\
\hline
\end{tabular}

Tablo 3 incelendiğinde, okuma yazmaya hazırlık sürecinde ailelerin rolüne ilişkin katılımcıların hem olumlu hem de olumsuz görüşlere sahip olduğu belirlenmiştir. Araştırmaya katılan anneler çocuklarının okuma yazma becerilerini nasıl destekleyeceklerini bilmediklerini, bu işin öğretmen ya da okula bırakılması gerektiğini ya da harf öğretimi girişimlerinde zorlandıklarını belirterek olumsuz yönde düşüncelerini dile getirmişlerdir. Çok az sayıda anne çocuklarının okuma yazma becerilerini geliştirerek sürece katkı sağladıklarını ve bunun çocuğa pek çok yarar sağladığını belirtmiştir. Bu konuda 2. katılımcı görüşlerini şu şekilde ifade etmiştir.

“Ailelerin bu işe karışmaması gerektiğini düşünüyorum. Çünkü çocuklar üzerinde baskı kurarak bir şeyleri öğretmeye çalıştıkları için faydadan çok zarar veriyorlar. Ayrıca çok istesem de neler yapabileceklerim konusunda çok fazla şey üretemiyorum. "

Katılımcılara "Çocuklarınızın okuma yazmaya hazırlık becerilerini desteklemek için evde neler yapıyorsunuz? sorusu yöneltilmiş ve katılımcıların cevaplarına ilişkin bulgular Tablo 4'te sunulmuştur. 
Tablo 4. Okuma yazmaya hazırlık becerilerini desteklemek için evde yapılan çalışmalara ilişkin bulgular

\begin{tabular}{lc}
\hline Çalışmalar & $f$ \\
\hline Boyama etkinlikleri & 18 \\
Harf ögretimi & 10 \\
Kitap okuma & 9 \\
Sözcük oyunları & 6 \\
Ses oyunları & 4 \\
\hline
\end{tabular}

Tablo 4'e göre, annelerin çoğu çocuklarının okuma yazmaya hazırlık becerilerini desteklemek için evde boyama etkinlikleri yaptıklarını belirtmişlerdir. Bu konuda 2. katılımcı görüşlerini şu şekilde ifade etmiştir.

"Çalışma ve boyama kitapları alıyoruz ve onları tamamlıyoruz. "

Çocukların okuma yazmaya hazırlık çalışmalarına gösterdikleri tepkilere ilişkin bulgular Tablo 5 'te sunulmuştur.

Tablo 5. Çocukların okuma yazmaya hazırlık çalısmalarına tepkilerine ilişkin bulgular

\begin{tabular}{cc}
\hline Görüşler & $\mathrm{f}$ \\
\hline Yapmak istememe & 12 \\
İlgisizlik ve keyif alamama & 10 \\
Dikkatini yoğunlaştıramama & 6 \\
Psikomotor yetersizlikler & 5 \\
İstekli ve hevesli olma & 5 \\
\hline
\end{tabular}

Tablo 5 incelendiğinde, annelerin çoğu çocukların okuma yazmaya hazırlık etkinliklerinde olumsuz tepkiler (isteksizlik, keyif almama, dikkatini yoğunlaştırmama ve psikomotor zorlanmalar) gösterdiklerini belirtmişlerdir. Sadece 5 anne çocukların okuma yazmaya hazırlık çalışmalarını yapmaya istekli olduklarını ifade etmiştir. Bu konuda 18. katılımcı görüşlerini şu şekilde ifade etmiştir.

"Boyama kitabını verdiğimde önce çok heveslenip boyamaya başlıyor ancak bu çok uzun sürmüyor.

Anne sıkıldım deyip başka şeylerle uğraşıyor. Ben de zorlamak istemiyorum ”

Katılımcılara "Çocuklarınızı okuma yazmaya hazırlama konusunda kendinizi yeterli hissediyor musunuz? sorusu yöneltilmiş ve bulgular Tablo 6'da sunulmuştur.

Tablo 6. Ailelerin okuma yazmaya hazırlık konusundaki yeterlik algılarına ilişkin bulgular

\begin{tabular}{lc}
\hline Yeterlilik algiları & $\mathrm{f}$ \\
\hline Evet & 9 \\
Hayır & 14 \\
Kararsızım & 2 \\
\hline
\end{tabular}

Tablo 6'ya göre, araştırmaya katılan annelerin çoğu çocuklarını okuma yazmaya hazırlama konusunda kendilerini yetersiz hissettiklerini belirtmişlerdir. Bu konuda 14. katılımcı görüşlerini şu şekilde ifade etmiştir.

"Yeterli hissetmiyorum, çünkü kitap okumak dışında ne yapmam gerektiğini bilmiyorum. Bir de çocuğum harfleri gösterip sorunca söylüyorum.” 


\section{Aile Temelli Okuma Yazmaya Hazırlık Programının Sonrasında Annelerin Okuma Yazmaya Hazırlık Konusundaki Görüşlerine İlişkin Bulgular}

Aile Temelli Okuma Yazmaya Hazırlık Programı tamamlandıktan sonra annelere programın başlangıcında sorulan sorular yeniden yöneltilmiş ve elde edilen bulgular sırayla sunulmuştur. İlk olarak "Okuma yazmaya hazırlık becerileri denince aklınıza neler geliyor? Okuma yazmaya hazırlamak için çocuklara hangi becerileri kazandırmalıyız?" soruları yöneltilmiş ve katılımcıların cevaplarına ilişkin bulgular Tablo 7'de sunulmuştur.

Tablo 7. Okuma yazmaya hazırlık becerilerinin tanımına/içeriğine ilişkin bulgular

\begin{tabular}{lc}
\hline Tanımlar/ İçerikler & $\mathrm{f}$ \\
\hline Ses farkındalı̆̆ı becerisine yönelik tanımlar/içerik & 18 \\
Sözcüklerin başlangç ve son sesini söyleme & 17 \\
Aynı sesle başlayan sözcükleri bulma & 14 \\
Aynı sesle biten sözcükleri bulma & 12 \\
Ritimli sözcükleri fark etme & 24 \\
Yazma becerisini desteklemeye yönelik tanımlar/içerik & 24 \\
Çeşitli çizgi çalışmaları & 18 \\
Boyama etkinlikleri & 16 \\
Kağıt kesme, katlama, yapıştırma & \\
Yazının yönünü (soldan sağa, yukarıdan aşağıya) gösterme & 25 \\
Kalem tutma & 18 \\
Dinleme ve konuşma becerisine yönelik tanımlar/içerik & 19 \\
Kitap okuma & \\
Duygu ve düşüncelerini ifade etme & 16 \\
Sözcük dağarcığını desteklemeye yönelik tanımlar/içerik & 15 \\
Yeni ö̈cükleri öğrenmesine yardım etme & 19 \\
Alfabe bilgisine yönelik tanımlar/içerik & 13 \\
Harf öğretimi & \\
Büyük harf, küçük harf farkındalığı & \\
Görsel algı becerisine yönelik tanımlar/içerik & \\
Resimleri anlatma & \\
Benzerlik ve farklıklar hakkında konuşma &
\end{tabular}

Tablo 7 incelendiğinde, ikinci görüşmelerde annelerin tanımlarında ve açıklamalanında farklılık ve çeşitlilik görülmektedir. Araştırmanın başlangıcında annelerin okuma yazmaya hazırlık becerilerini ifade ederken yazmaya hazırlık ve alfabe bilgisi üzerinde odaklandığı diğer becerileri göz ardı ettikleri belirlenmişti. Ancak programdan sonra anneler bütün okuma yazmaya hazırlık becerilerine dikkat çeken açıklamalarda bulunmuşlardır. Bu bulgu uygulanan programın, ailelerin okuma yazmaya hazırlık becerilerine ilişkin görüşlerinde üzerinde olumlu etkiler yarattı̆̆ını göstermektedir.

Katılımcılara "Okul öncesi dönemde okuma yazmaya hazırlık çalışmalarının gerekli olduğunu düşünüyor musunuz? Neden? soruları yöneltilmiş ve katılımcıların cevaplarına ilişkin bulgular Tablo 8'de sunulmuştur.

Tablo 8. Okul öncesi dönemde okuma yazmaya hazırlık çalışmalarının gerekliliğine ilişkin bulgular

\begin{tabular}{lc}
\hline Görüşler & $f$ \\
\hline Gerekli & 22 \\
Gereksiz & 2 \\
\hline
\end{tabular}


Araştırmaya katılan annelerin çoğu okul öncesi dönemde okuma yazmaya hazırlık çalışmalarının gerekli olduğunu ifade etmiştir. Katılımcıların okuma yazmaya hazırlık sürecinde ailelerin rolüne ilişkin görüşleri Tablo 9'da sunulmuştur.

Tablo 9. Okuma yazmaya hazırlık sürecinde ailelerin rolüne ilişkin bulgular

\begin{tabular}{lc}
\hline Görüşler & $\mathrm{f}$ \\
\hline Olumlu görüşler & 19 \\
Destek olma & 17 \\
Evde firsatlar yaratma, ortam düzenleme & 15 \\
Çocuk açısından önemini vurgulama & 15 \\
Aile açısından önemini vurgulama & 3 \\
Olumsuz görüşler & 3 öretmenlere birakma \\
Sorumluluğu ögretma
\end{tabular}

Tablo 9'a göre, ikinci görüşmelerde ailelerin çoğu okuma yazmaya hazırlık sürecinde ailelerin rolüne ilişkin olumlu yönde görüş belirtmişlerdir. Programın sonrasında yapılan görüşmelerde annelerin, okuma yazmaya hazırlıkla ilgili etkinlikler planlama ve uygulama, okuryazarlıkla ilgili farkındalık ve olumlu tutum geliştirme konularında ailelerin rol üstlenmesi gerektiğini vurguladıkları, okuma yazmaya hazırlıkla bağdaşmayan uygulamalardan kaçındıkları belirlenmiştir.

Katılımcılara "Çocuklarınızın okuma yazmaya hazırlık becerilerini desteklemek için evde neler yapıyorsunuz? sorusu yöneltilmiş ve katıllımcıların cevaplarına ilişkin bulgular Tablo 10'da sunulmuştur.

Tablo 10. Okuma yazmaya hazırlık becerilerini desteklemek için evde yapılan çalışmalara ilişkin bulgular

\begin{tabular}{lc}
\hline Çalışmalar & $\mathrm{f}$ \\
\hline Boyama etkinlikleri & 22 \\
Kitap okuma & 21 \\
Sözcük ve kavram öğretimi & 18 \\
Ses farkındalığına yönelik oyunlar & 17 \\
İnce kas becerisine yönelik etkinlikler & 16 \\
Görseller hakkında konuşma & 16 \\
Benzerlik ve farklılıkları ayırt etme etkinlikleri & 13 \\
Harf öğretimi & 7 \\
\hline
\end{tabular}

Tablo 10 incelendiğinde, annelerin ikinci görüşmelerde evde çocukları için sağladıkları fırsatların arttığı belirlenmiştir. Bu durumun katıldıkları eğitim programıyla ilişki olduğu düşünülmektedir. Aileler katıldıkları programda okuma yazmaya hazırlık becerilerinin içeriğine ve uygulamasına ilişkin pek çok bilgi, beceri edinme firsatına sahiptir. Ailelerin program süresince edindikleri deneyimleri evde planlama ve uygulama aşamasında kullandıkları düşünülmektedir. Elde edilen bu bulgular uygulanan programının ailelerin okuma yazamaya hazırlıkla ilgili evde yaptıkları uygulamalara yansıdığını göstermiştir.

Çocukların okuma yazmaya hazırlık çalışmalarına gösterdikleri tepkilere ilişkin bulgular Tablo 11'de sunulmuştur. 
Tablo 11. Çocukların okuma yazmaya hazırlık çalışmalarına tepkilerine ilişkin bulgular

\begin{tabular}{cc}
\hline Tepkiler & $\mathrm{f}$ \\
\hline İstekli ve hevesli olma & 16 \\
Tek başına uzun süre etkinliği sürdürebilme & 8 \\
Etkinlikleri keyifle sürdürme ve tamamlama & 7 \\
Psikomotor yetersizlikler & 5 \\
\hline
\end{tabular}

Tablo 11 incelendiğinde, programdan sonra annelerin çoğu çocukların okuma yazmaya hazırlık etkinliklerinde olumlu tepkiler yansıttıklarını belirtmişlerdir. Sadece 5 anne kalem tutmayı başaramama, çizgi çalışmalanında zorlanma gibi psikomotor yetersizliklere vurgu yapmışlardır. $\mathrm{Bu}$ konuda 24. katılımc1 görüşlerini şu şekilde ifade etmiştir.

“Artık birlikte ve daha eğlenceli etkinlikler yaptığımız için daha dikkatli ve istekli davranıyor."

Katılımcılara "Çocuklarınızı okuma yazmaya hazırlama konusunda kendinizi yeterli hissediyor musunuz? sorusu yöneltilmiş ve bulgular Tablo 12'de sunulmuştur.

Tablo 12. Ailelerin okuma yazmaya hazırlık konusundaki yeterlik algılarına ilişkin bulgular

\begin{tabular}{ll}
\hline Yeterlilik algiları & $\mathrm{f}$ \\
\hline Evet & 19 \\
Hayır & 5 \\
Kararsizım & 1 \\
\hline
\end{tabular}

Tablo 12'ye göre ikinci görüşmelerde çocuklarını okuma yazmaya hazırlama konusunda kendilerini yeterli hisseden annelerin sayısı artmıştır. Bu konuda 18. katılımcı görüşlerini şu şekilde ifade etmiştir.

'Yeterli hissediyorum, çünkü evde çocuğumla yapabileceğim pek çok oyun ve etkinlik biliyorum artık.

Ayrıca nerde yanlış yaptı̆̆ımı öğrendim umarım bir daha yapmam.'”

\section{SONUÇ ve TARTIŞMA}

Annelerin erken okuryazarlık konusundaki görüş ve uygulamalarının incelendiği bu araştırmanın sonucunda, uygulanan programın sonrasında ailelerin okuma yazmaya hazırlık becerilerine ilişkin görüşlerinde farklılık olduğu, bu sürecin evde firsatlar oluşturma, etkinlikler planlama ve uygulama sürecine olumlu yönde yansıdığı, okuma yazmaya hazırlıkla bağdaşmayan uygulamaları azalttı̆̆1 belirlenmiştir. Ho (2002), okul-aile etkileşimini incelemek amacıyla yürüttüğü çalışmada ebeveynlerin şu konu başlıklarını vurgulandığını belirtmiştir: “okulla daha çok iletişim kurma, çocuklarına eğitimlerine nasıl destek olabilecekleri konusunda bilgiye ulaşma isteği, okullardan memnun olma, ebeveynlik görevlerini yerine getirebilmek için programlar ve hizmetler talep etme.” $\mathrm{Bu}$ nedenle okul-aile etkileșiminin niteliğinin geliştirilmesi, ailelerin ihtiyaç hissettikleri alanlara yönelik programların hazırlanması önemlidir. Bu hedefe hizmet eden programların geliştirilmesi için ailelerin okuryazarlık konusuna ilişkin düşüncelerini ve uygulamalarını belirlemek gerekir. Fakat 
ilgili alan yazında bu ihtiyaçları gidermeye yönelik programlar sınırlıdır (Özen Altınkaynak, 2014). Araştırma kapsamında uygulananı programda ailelerin hazırbulunuşluk düzeylerinin belirlenmesi, erken okuryazarlık konusunda teorik bilgilerin yanında etkinlik örnekleri ile uygulama firsatlarının verilmesi sayesinde ikinci görüssmelerde annelerin görüss ve uygulamalarında olumlu yönde değişme olduğu ifade edilebilir.

Farklı aile okuryazarlık programlarına katılan ebeveynlerin alg1 ve deneyimlerini belirlemek amaciyla Swain, Brooks ve Bosley (2014) tarafindan yürütülen boylamsal araştırmanın sonucunda, bu tür programların, aileye, çocuğa ve topluma birçok fayda sağladığını belirlenmiştir. Aileler çocuklarının eğitimlerine nasıl destek olabilecekleri konusunda bilgi sahibi olmuş, eğitim sürecinde yer almaya istekli davranmış, kendilerinin okuryazarlık düzeylerini geliştirmeye yönelik girişimlerde bulunmuş, eğitimle ilgili anlayış geliştirmişlerdir. Bu sonuçlar araştırmanın bulguları ile paralellik göstermektedir. Araştırma kapsamında gerçekleştirilen ikinci görüşmelerde annelerin okuma yazmaya hazırlık konusundaki görüş ve uygulamalarının olumlu yönde farklılaştı̆̆ı belirlenmiştir. Program kapsamında ailelerin okuma yazmaya hazırlık konusunda yanlış bilgilerin düzeltilmesi ve yeni bilgiler edinilmesi, edinilen bilgilerin evde uygulama fırsatı bulma sayesinde ikinci görüşmelerde ailelerin görüş ve uygulamalarının olumlu yönde değiștiği düşünülmektedir.

Araştırmaya katılan annelerin çoğunluğu birinci görüşmelerde çocuklarını okuma yazmaya hazırlama konusunda kendilerini yetersiz hissettiklerini belirtmesine rağmen ikinci görüşmelerde bu sayı azalmışır. Araştırmacılar ailelerin yeterliliklerine ilişkin inançlarıyla ev ortamında çocukların okuma yazma etkinliklerine katılımları arasında ilişki bulmuştur. Saracho (1997), ailelerin sahip olduğu yeterlilik algılarıyla çocuklarıyla kurdukları okuryazarlık etkileşimleri arasında ilişki olduğunu belirtir. Ortiz (2005), ailelerin okuryazarlığa ilişkin tutumlarının çocukları için yapmayı düşündükleri okuma yazma etkinliklerini, bu etkinliklere ayırdıkları zamanı etkilediğini vurgular. Ev temelli okuma yazmaya hazırlık programının ailelere etkisini araştıran Press (2008), deney grubunda bulunan ailelere 8 hafta süren bir program uygulanmıştır. Araştırmanın sonucunda bu programın, ailelerin bilgi ve düşüncelerinin niteliğinde ve düzeyinde olumlu bir etki yarattığı belirlenmiștir. Bu araştırma kapsamında programa katılan anneler kendini ifade etme, çocuklarının gelişimini ve eğitimini destekleyecek bilgiler edinme, öğretmenle ve diğer ailelerle iletişim kurma ve birlikte çalışma gibi fırsatlar elde etmişlerdir. Bu deneyimler annelerin kendilerine güvenlerini artırır. Edinilen bilgi ve deneyimler sayesinde ikinci görüşmelerde annelerin okuma yazmaya hazırlıkla konusundaki düşüncelerinin olumlu yönde değiştiği düşünülmektedir. Altıparmak (2010) annebabaların okuma-yazmaya hazırlıkla ilgili görüşlerini belirlemeyi amaçladığ1 araştırmanın sonucunda, ailelerin ses farkındalı̆̆ını arttıran ninni ve tekerleme gibi etkinlikleri çok fazla kullanmadıkları, okuma-yazmaya hazırlıkla ilgili ev uygulamaları konusunda farklı süreler ayırdıkları 
belirlenmiştir. Ailelerin çocukların okuma yazmaya hazırlık becerilerini edinmesinde önemli rol oynadığ1 araştırmalarda açık şekilde vurgulanmaktadır. $\mathrm{Bu}$ nedenle ailelere okuma yazmaya hazırlıkla ilgili evde uygulayabilecekleri konusunda destek olan müdahale programları geliştirmek ve uygulamak önemlidir.

Araştırmaya katılan ailelerin evde yaptıkları okuma yazmaya hazırlık etkinliklerinin ve bu konuda çocuklarına sağladıkları firsatların ikinci görüşmelerde arttığı belirlenmiştir. Bu bulgu ilgili alan yazındaki araştırmalar ile paralellik göstermektedir. Yapılan araştırmalar, bu tür programlara katılan ailelerin aile-çocuk etkileşimlerinin arttı̆̆ını göstermektedir (Padak, Sapin, Baycich, 2002; Saracho, 2007). Bu programlardan yararlanan aileler çocuklarına sıkça kitap okurlar, kütüphanede çocuklarıyla daha çok zaman geçirirler, çocukların okuluyla iletişim halinde olmaya daha isteklidirler (Padak, Sapin, Baycich, 2002). Parks'ın (1995), risk altındaki ailelere yönelik aile okuryazarlık programının ailelere ve çocuklara etkisini değerlendirdiği araştırmanın sonucunda, programdan sonra ailelerin eğitime verdikleri değerin olumlu yönde değiştiği belirlenmiştir. Ailelerin eğitim etkinliklerine katılımlarında ve çocuklara ilişkin pozitif davranışlarında artma gözlenmiştir. Ayrıca öğretmenler de aile okuryazarlık programına katılan ailelerin, çocuklarına pozitif tutumlar gösterdiklerini ve çocuklarının erken okuryazarlık becerilerini pozitif etkilendiğini belirtmişlerdir. $\mathrm{Bu}$ araştırmada program süresince ailelerin okuma yazmaya hazırlık çalışmalarını tüm yönleriyle ele alması, yalnızca el-göz koordinasyonu ya da harflerin öğrenilmesi olarak ele alınmaması ailelere okuma yazmaya hazırlamak için yapabileceklerinin niteliğinde artışa yol açmıs olabilir. Program sürecindeki uygulama örneklerinin, ailelerin okuma yazmaya hazırlıkla ilgili etkinlikleri planlama ve uygulama durumlarına yansımış olabileceği düşünülmektedir

Araştırmanın sonuçları doğrultusunda şu öneriler geliştirilebilir: Yurt dışındaki gibi farklı yoğunlukları olan ve farklı boyutlardan oluşan aile okuryazarlık programları geliştirilmeli, bu programların etkilerine ilişkin araştırmalar yürütülebilir. Aileler evde oluşturacakları nitelikli erken okuryazarlık ortamları (yazılı uyaranların olduğu, çocukların okuma yazmaya hazırlık becerilerini destekleyecek materyallerin yer aldığı, etkileşimli öğrenmelere firsat verecek fiziksel düzenlemelerin ortamlar) ile çocukların eğitimine destek olacak fırsatlar oluşturmalıdır. Nicel araştırma deseninin kullanıldığı, ailelerin erken okuryazarlık sürecine yönelik yaptıkları ile çocukların erken okuryazarlık becerileri (sözcük dağarcığı, ses ve yazı farkındalığı, görsel alg1, dinleme ve konuşma gibi) arasındaki ilişkiyi inceleyen araştırmalar alana katkı sağlayacaktır.

\section{KAYNAKÇA}


Altıparmak, S. (2010). Erken çocukluk döneminde ebeveynlerin okuma-yazmaya bazırlk konusundaki görïsleri. Yayınlanmamış Yüksek Lisans Tezi. Orta Doğu Teknik Üniversitesi Sosyal Bilimler Enstitüsü, Ankara.

Baydar, N., Küntay, A., Gökşen, F., Yağmurlu, B. ve Cemalcılar, Z. (2010). Türkiye'de erken çocukluk gelişim ekolojileri araștırması (Proje No. 106K347). İstanbul: Koç Üniversitesi.

Büyüköztürk, Ş., Kılıç Çakmak, E., Akgün, Ö. E., Karadeniz, Ş. ve Demirel, F. (2014). Bilimsel araștırma yöntemleri. Ankara: PegemA.

Carson, J. H. (2009). Mothers as partners in early childhood education: comparison of an even start and a family resource center program. Unpublished Doctoral Dissertation, Brandeis University, Boston.

Erkan, S. (2013). Aile ve aile eğitimi ile ilgili temel kavramlar. F. Temel (Editör), Aile eğitimi ve erken çocukluk eğitiminde aile katılım çallşmalar içinde, 248 (2. Baskı). Ankara: Anı Yayıncılık.

Gül, G. (2007). Okuryazarlık sürecinde aile katılımının rolü. Ankara Üniversitesi Eğitim Bilimleri Fakültesi Örel Ë̈itim Dergisi, 8(1), 17-30.

Güleç, G. (2008). Okul öncesi eğitim ögrretmenlerinin okuma yazmaya hazırllk çalıșmalar ile ilgili görüs ve uygulamaları. Yayınlanmamış Yüksek Lisans Tezi. Pamukkale Üniversitesi, Sosyal Bilimler Enstitüsü, Denizli.

Güleç, H., Genç, S. Z. ve Şahan, B. (2014). Okul öncesi çocuklarının aileleri ile birlikte yaptıkları okuma yazma çalışmalarının belirlenmesi. M. Riedler, M.Y. Eryaman, H. Dedeoğlu, N. Cerrahoğlu ve E. Yolcu (Eds.), VI. Uluslararası Türkiye Eğitim Arastırmalar Kongresi icinde (s. 721-729). Ankara: Hacettepe Üniversitesi.

Hannon, P. \& Weinberger, J. (2003). Family Literacy. Unit 7 of Literacy in a Wider Context. Department of Educational Studies, University of Sheffield, Sheffield, U.K

Harper, S., Platt, A. \& Pelletier, J. (2011). Unique effects of a family literacy program on the early reading development of english language learners. Early Education and Development, 22(4), 9891008 .

Ho, B.S. (2002). Research into practice: Application of participatory action research to familyschool intervention. School Psychology Review, 31(1), 106-121.

Kalkan, E. (2010). Dünyada anne baba eğitimi ve aile katılımı: Amerika Birleşik Devletleri örneği. T. Güler (Editör), Anne Baba Eğitimi içinde, 165-182. Ankara: PegemA Akademi.

Mahmood, S. (2013). First-year preschool and kindergarten teachers: challenges of working with parents. School Community Journal, 23(2), 55-85.

Miles, M. B., Huberman, A. M. (1994). Qualitative data analysis: An expanded sourcebook $\left(2^{\text {nd }} \mathrm{ed}\right)$. CA: Sage Publication.

National Association for the Education of Young Children. (2011). 2010 NAEYC standardsforinitialandadvancedearlychildhoodprofessionalpreparationprograms. Washington, DC: NAEYC. 
Ortiz,R.W.(2004).Hispanic/Latino fathers and children literacy development examining involvement practices from a sociocultural context. Journal of Latinos and Education, 3(3), 165180.

Özbek Ayaz, C. (2015). Ailelerin, okul öncesi dönemdeki çocuklarmm okuryazarllk becerilerini desteklemek

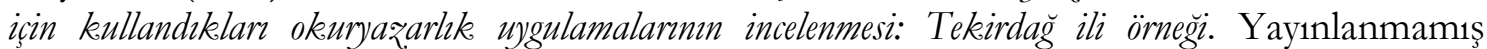
Yüksek Lisans Tezi. Çanakkale Onsekiz Mart Üniversitesi Eğitim Bilimleri Enstitüsü, Çanakkale.

Özen Altınkaynak, Ş. (2014). Aile temelli okuma yazmaya hazırlık programının cocukların okuma yazmaya hazırlık becerilerine etkisi. Doktora Tezৃ. Hacettepe Üniversitesi, Eğitim Bilimleri Enstitüsü, Ankara.

Padak, N.,Sapin, C. \&Baycich, D. (2002). A decade of family literacy: programs, outcomes and future prospects (No. Information Series No. 389). Columbus, OH: ERIC Clearinghouse on Adult, Careerand Vocational Education.

Parks, R. D. (1995). The influence of a family literacy program on low socio-economic families and their children. Unpublished Doctoral Dissertation, University of Miami, CoralGables.

Press, A. A. (2008). The effect of a home-based family literacy program on parents' involvement in their children's literacy development. Unpublished Doctoral Dissertation, University of Toronto, Toronto.

Saracho, O. N. (2007). Hispanic families as facilitators of their children's literacy development. Journal of Hispanic Higher Education, 6(2), 103-117.

Saracho, O. N. (2000). Literacy development in the family context. Early Child Development and Care, 165, 107-114.

Saracho, O.N. (1997). Perspectives on family literacy. Early Child Development and Care, 127-128: 311.

Swain, J.,Brooks, G. \&Bosley, S. (2014). The benefits of family literacy provision for parents in England. Journal of Early Childhood Research,12, 77-91.

Polat, Ö. (2011). Effects of technological equipment at home on school readiness of 5-6-year-old children. The New Educational Review, 24(2), 243-257.

Rasinski, T. \& Stevenson, B. (2005). The effects of fast start reading: A fluency-based home involvement reading program, on the reading achievement of beginning readers. Reading Psychology, 26, 109-125.

Training and Development Agencyfor Schools (TDA). (2008). Professional standardsforqualifiedteacherstatusandrequirementsforinitialteachertraining(Rev. ed.). Retrieved 5 December 2013 from https://www.education.gov.uk/publications/eOrderingDownload/tda0600.pdf.

Ulusal Aile ve Sosyal Araştırmalar Kamu Araştırma Programı. (2006). 9 Haziran 2012 tarihinde http://www.tubitak.gov.tr/tubitak_content_files/ARDEB/kamag/Ulusal_Aile_ve_ Sosyal_Arastirmalar_Kamu_Arastirma_Programi adresinden ulaşılmıştır. 
Unutkan, Ö. P. (2007). 5-6 yaş çocuklarının yaşadıkları evin yapısının ilköğretime hazır bulunuşluk düzeyine etkisi. Ondokuz Mayıs Üniversitesi Ë̆itim Fakültesi Dergisi, 24, 43-54.

Wasik, B. H. \&Herrmann, S. (2004). Family literacy: History, concepts, services. In B. H. Wasik (Ed.), Handbook of family literacy,3-22. Mahwah, NJ: Lawrence Erlbaum Associates. 